\title{
Mongolian Language
}

National Cancer Institute

\section{Source}

National Cancer Institute. Mongolian Language. NCI Thesaurus. Code C154034.

A Mongolic language that is the official language of Mongolia. 